\title{
Climate Change Predictions of Increased Watershed Flow in Atlantic Canada: Implications for Surface Water Vulnerability and Ameliorative Land Use Planning and Management
}

\author{
Robert L. France1, Peter W. Aitchison² \\ ${ }^{1}$ Department of Plant, Food, and Environmental Sciences, Faculty of Agriculture, Dalhousie University, Truro, Canada \\ ${ }^{2}$ Deceased, Department of Applied Mathematics, 424 University Centre, University of Manitoba, Winnipeg, Canada \\ Email:rfrance@dal.ca
}

How to cite this paper: France, R. L., \& Aitchison, P. W. (2019). Climate Change Predictions of Increased Watershed Flow in Atlantic Canada: Implications for Surface Water Vulnerability and Ameliorative Land Use Planning and Management. Journal of Geoscience and Environment Protection, 7, 162-176.

https://doi.org/10.4236/gep.2019.79012

Received: July 19, 2019

Accepted: September 23, 2019

Published: September 26, 2019

Copyright $\odot 2019$ by author(s) and Scientific Research Publishing Inc. This work is licensed under the Creative Commons Attribution International License (CC BY 4.0).

http://creativecommons.org/licenses/by/4.0/

\begin{abstract}
Essential for comprehensive and sustainable watershed management is the need to understand interactions between climate change predictions and landuse modifications in concert on ecohydrology. The Atlantic Canada region is expected to experience elevated rainfall due to climate change over the next century. We undertook a predictive modeling study of a watershed in rural Nova Scotia, Thomas Brook, to investigate the potential of riparian reforestation to mitigate the deleterious environmental effects projected to occur from future climate change. A Watershed Analysis Risk Management Framework (WARMF) model was used to predict increased watershed flows using data from projections of the Canadian Regional Climate Change Model. The cold climate-validated WARMF model, which has been used previously to simulate surface flow hydrology in many agricultural and mixed-use landscapes, was found to predict increases of $9 \%$ to $25 \%$ in flow for the Thomas Brook watershed throughout the rest of the century. A spatial, exposure-based model, used previously in several studies, was adopted for assessing changes in surface water vulnerability based on GIS land-use and landscape topography estimates of nutrient loading, sedimentation, runoff, wetland loss, and stream geomorphology. This model indicated that increases in drainage intensity and drainage sensitivity expected through the climate change WARMF model resulted in greater proportions (from 5\% to 27\%) of the Thomas Brook watershed area being classified as "High vulnerability" for impacting surface water quality. In terms of land use planning, implementation of runoff and
\end{abstract}


nutrient entrapment techniques through low impact development may need to become increasingly required in order to maintain aquatic health. In terms of land-use management, empirically increasing the width of riparian forest buffers was projected to reduce the predicted areal extent of "High vulnerability". However, widths of $90 \mathrm{~m}$ would be required in order to achieve the same degree of protection that presently exists. Our conclusions are that climate-proofing this watershed through riparian reforestation would come at a cost in terms of the extent of land needed to be set aside by being taken out of agricultural production or commercial forestry.

\section{Keywords}

Climate Change, Riparian Forests, Watershed Flow, Water Vulnerability

\section{Introduction}

Due to a dominating meteorological emphasis that largely or completely ignores potentially moderating influences of the landscape, many models of the projected effects of climate change on water resources operate in a vacuum of managerial reality. Essential for the long-term sustainable management of watersheds is the need to compare the influences of climate and landuse management factors in concert (Jones, 2011). Because of this recognition, more researchers are now undertaking studies that specifically focus on the combined impacts of future climate and landuse changes on water resources (Velasco et al., 2014; Tong et al., 2016). And some of this work is being undertaken in Canada (Novotna et al., 2014; El-Khoury et al., 2015), as well as the north-east bioregion of New England states and the Atlantic Canadian provinces (Talib \& Randhir, 2017; France et al., 2018).

Modification of vegetative cover (Nearing et al., 2004; De Munck et al., 2007), including the restoration of riparian forest buffer strips (France et al., 2018), has been suggested as a best management practice (BMP) to mitigate climate change-induced alterations in erosion. The purpose of the present study was to expand upon previous work (France \& Pardy, 2018) concerning landscape influences on surface water vulnerability for a small, rural watershed in Nova Scotia, Canada that has been the subject of extensive study on the aqueous contamination of sediment, nutrients, and bacteria (Jamieson et al., 2003; Sinclair et al., 2009; Ahmad et al., 2011; Amon-Armah et al., 2013).

The previous 2018 paper (France \& Pardy, 2018) was focused solely upon land use planning and dealt with the current state of affairs. The present work extends the analysis through futures modeling. In particular and firstly, herein we model the projected effects of regional climate change, vis-à-vis increased rainfall and therefore consequent higher runoff, and examine how this will influence the proportion of land classified as being of "High vulnerability" with respect to impacting water quality. And, secondly, we model how implementing different 
climate change mitigation scenarios of variable buffer strip width might influence the areal proportion of land in the watershed deemed to be of "High vulnerability". In both cases, land use planning and management implications are discussed. In summary, our interest is to examine, through new predictive modeling, the potential for riparian reforestation to offset deleterious environmental effects that are projected under the auspices of future climate change scenarios.

\section{Study Area}

Our climate change model was applied to the Thomas Brook watershed, located in the Annapolis Valley of Nova Scotia (see regional maps in Ahmad et al., 2011; Amon-Armah et al., 2013; France \& Pardy, 2018). This small, 784 ha watershed is part of the larger $360 \mathrm{~km}^{2}$ Cornwallis River watershed draining into the Bay of Fundy. The stream network is relatively simple, with several upland streams merging into a single channel about a third of the way down the watershed, with a total linear drainage length of about $6 \mathrm{~km}$, all being fed by rainfall, ephemeral rivulets, and groundwater seepage. The average channel slope is $3.5 \%$, being steeper in the upper watershed $(>10 \%)$ and shallower in the lower reaches $(0.5 \%-1.3 \%)$. Soils are predominantly reddish brown sandy loam (Cann et al, 1965). Land-use is varied, being primarily (ca 57\%) agriculture (Sinclair et al., 2009), with large patches of forest in the upper watershed and numerous dwellings in the mid- to lower watershed (Figure 1; see representative landscape photos in France \& Pardy, 2018).

The Thomas Brook watershed has experienced degradation of both surface and groundwater quality due to agricultural and residential development (Jamieson et al., 2003; Sinclair et al., 2009). Because of this, the watershed was selected to be part of a long-term research program of Agriculture and Agri-Food Canada (2007), in particular through being representative of small, coastal watersheds in Atlantic Canada which experience nutrient loss (Ahmad et al., 2011; Amon-Armah et al., 2013). As a result, the Watershed Evaluation of Beneficial Management Practices (WEBs) program was set up to assess the environmental and economic impacts of different BMPs through hydrologic models of sediment and nutrient export.

\section{Methods}

\subsection{Climate Change Model}

We developed realistic predictions of regional climatic changes in precipitation amounts, and therefore watershed flow, for the Thomas Brook watershed through use of projections from the Canadian Regional Climate Model (CRCM) and the Watershed Analysis Risk Management Framework (WARMF) model.

Historical and measured meteorological data were obtained from Environment Canada Nova Scotia and used in the CRCM to generate projections based on four time frames: Scenario 1-the moderate or short-term past 1962-1990 


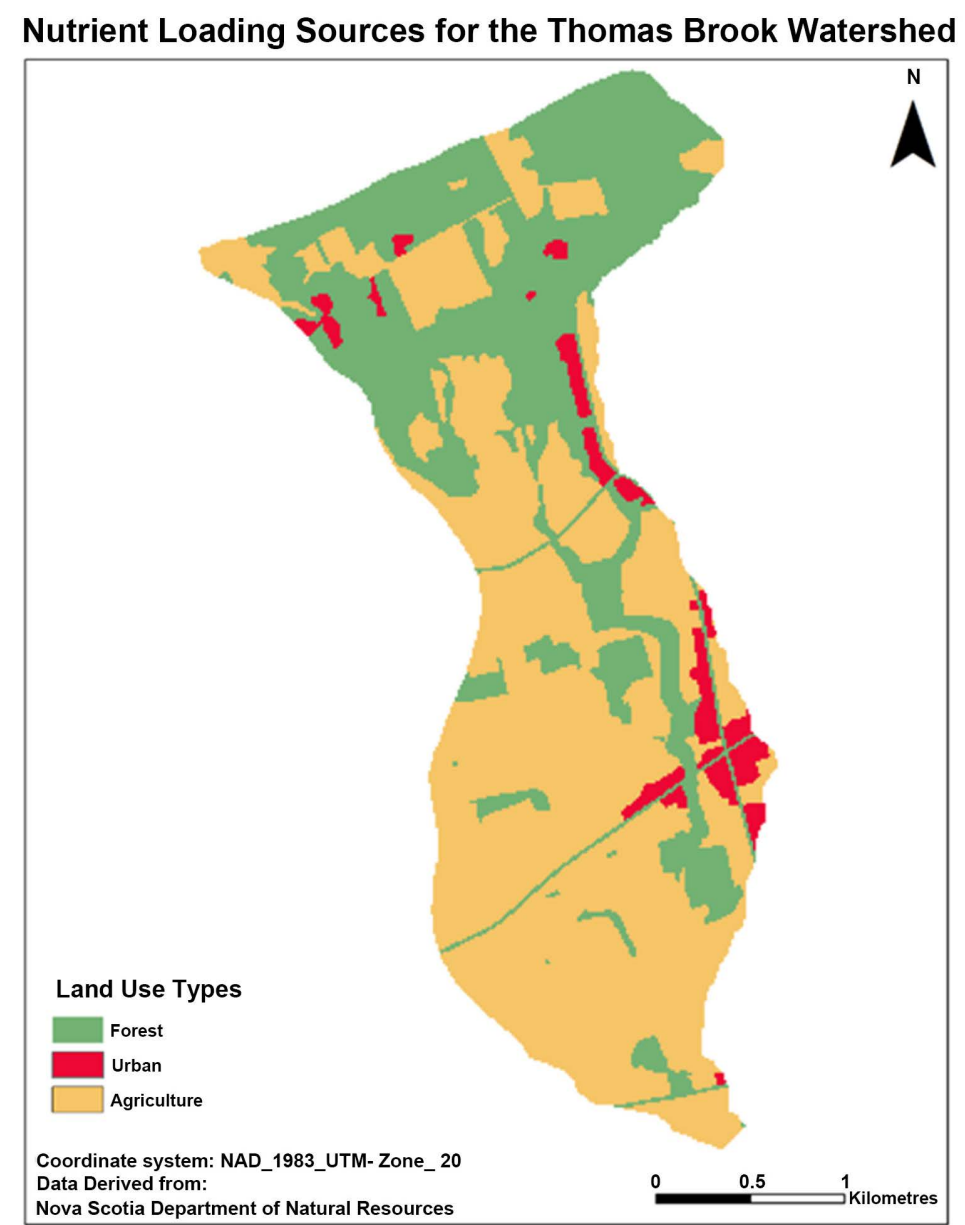

Figure 1. Landuse in the Thomas Brook watershed used to estimate nutrient loading for the water vulnerability model of Purdum (1997) as applied to the Nova Scotia watershed by France \& Pardy (2018), and as described in the text.

("M P"), Scenario 2-the present or near future 2011-2040 ("P/N F"), Scenario 3-the moderate or short-term future 2041-2070 ("M F"), and Scenario 4-the more distant or long-term future 2071-2099 ("M D F"), following the Intergovernmental Panel on Climate Change (IPCC)'s Special Report on Emissions (SRES) scenarios for North America over this period. The CRCM is a limited-area nested model, based on fully elastic non-hydrostatic Euler equations (Madani, 2010) solved by a non-centered algorithm (Laprise et al., 1998; Caya \& Laprise, 1999). The CRCM uses a polar stereographic projection on a horizontal grid with vertical resolution made based on height terrain (Madani, 2010) as described in Scinocca \& McFarlane (2004) and Music \& Caya (2007). Climate model outputs included maximum, minimum, and mean annual temperatures, and corresponding average precipitation amounts, which were then inputted into the watershed model.

The WARMF model is believed by experienced water resource engineers to offer potential benefits to agricultural planners through its integration of both 
historical (i.e. long-term climate datasets) and future projected (i.e. general circulation models and GCM outputs) climate data (Madani, 2009). WARMF is a moderate spatial resolution, watershed-scale model used to simulate surface flow hydrology and water quality in agricultural and mixed-use landscapes (Chen et al., 1998). The model has been peer-reviewed (EPRI, 2000) and successfully applied in more than a dozen (mostly US) watershed studies (Keller et al., 2004; USEPA, 2009; see additional case studies cited in Dayyani et al., 2013). The WARMF model was calibrated and cold-climate validated for an agricultural watershed in Quebec, were it was found to be able to accurately (i.e. $\mathrm{R}^{2}$ of 0.92 between observed and simulated values) estimate hydrology and nutrient loading under different land use management and climatic scenarios (Dayyani et al., 2013). The present study uses the model formulations detailed in Chen et al. (1998) as adapted to Canadian climate conditions by Dayyani et al. (2013), to estimate daily surface flows at the outlet of our target watershed for each of the four climate change timeframe scenarios.

Inputs to run the CRCM climate simulations of the WARMF model for the Thomas Brook watershed were obtained from Madani's (2010) reworking of tabulated GIS data on soils, land use, hydrologic boundaries, stream network, watershed slope, aspect, and width (all via DEM) from Ahmad et al. (2011) and for Manning's roughness coefficient (n) for each sub-basin land type from a standard hydrology handbook.

\subsection{Watershed Landscape Model}

We next examined the influence of forested riparian buffers on mitigating the projected effects of climate change as predicted by the WARMF model. This was accomplished through use of the spatial, exposure-based model of Purdum (1997), originally developed for an agricultural township in Michigan, and applied to the Thomas Brook watershed by France \& Pardy (2018). The model results are GIS-created maps of surface water vulnerability. Of importance is the finding from the previous work in the Thomas Brook watershed that shows a strong concordance in the derived mapped outputs between the time-efficient and cost-effective Purdum model and those obtained over multiple years using detailed, effects-based hydrologic models (Ahmad et al., 2011), thereby demonstrating the utility of the present, simple geospatial model.

As detailed in Purdum (1997) and France \& Pardy (2018), surface water vulnerability is assessed based on the serial integration and evaluation of three types of spatially-explicit geographic data: 1) Sources of Land Use-induced Change, 2) Intensity of Drainage, and 3) Sensitivity of Drainage Basins to Change. The model is based on the step-wise inclusion of information contained within three to four simple rankings categorized based on values obtained from the literature and expressed (i.e. mapped) as dimensionless variables (Purdum, 1997). Data types and sources are provided in France \& Pardy (2018). The first step of model development is to determine the Sum of Sources of Land Use-induced Change. This was determined by integrating database overlays from 5 spatially-assessed 
variables: nutrient loading (based on landuse, Figure 1), erosion and sedimentation, stormwater runoff, adjacent wetland loss, and alteration of stream morphology. Identification of the locations more susceptible to change is estimated by the drainage intensity, which is dependent on the area of the drainage basin, land use and cover typology, and the movement of rainfall through the drainage network (Marsh, 1997). By using a simulation of a 100-year storm, the estimated peak discharges are compared and categorized as low, medium, or high potential energy in the landscape to affect change. Output was calculated using the "flow accumulation" tool in ArcGIS with the DEM as an input. This allows an output of accumulated weight of all cells flowing into adjacent downslope cells which are then reclassified into the ranks above. The assessment of the Intensity of Change is determined from a matrix combining each location's drainage intensity with its previously derived Sum of the Sources of Land Use-Induced Change. The shape of the land will influence the movement of runoff and the consequent transport of contaminants (Ferguson \& Debo, 1989). The potential for this to occur is based on a location's surrounding topography (Purdum, 1997). The output is the result of a matrix of ranked proximity to a stream, depth of the water table, and flow accumulation. Sensitivity of drainage basin zones (Figure 2) were categorized as low for upland locations where dispersed overland sheet flow will occur, medium for collection zones in which runoff is concentrated, and high for conveyance zones where runoff can directly enter surface waters. The final assessments of the Vulnerability to Change of surface waters is determined from a matrix combining each location's sensitivity of drainage basin zones with its previously derived Intensity of Change.

Existing conditions in the watershed (France \& Pardy, 2018) were determined to be the following: $96.0 \%, 0.8 \%$, and $3.2 \%$ of the watershed area represented respectively by Low, Medium, and High drainage intensity; $8.6 \%, 67.7 \%$, and $17.7 \%$ of the watershed represented respectively by Low, Medium, and High drainage sensitivity (Figure 2); and finally $14.3 \%, 20.1 \%$, and $65.6 \%$ of the watershed represented respectively by Low, Medium, and High Vulnerability to Change. As mentioned, there was a strong concordance between the precise locations designated to be of the High vulnerability category and those areas deemed to pose the most serious threat to contaminating water determined by the SWAT model of Ahmad et al. (2011).

We examined four scenarios of climate change due to the WARMF model predictions of increased watershed flow: Scenario 1-ascribing all Medium drainage sensitivity polygons in Figure 2 to Medium drainage intensity; Scenario 2-ascribing all High drainage sensitivity polygons to Medium drainage intensity; Scenario 3-ascribing all High drainage sensitivity polygons to High drainage intensity; and the combined worst case example of Scenario 4-ascribing all Medium drainage sensitivity polygons to Medium drainage intensity as well as ascribing all High drainage sensitivity polygons to High drainage intensity. The goal was to determine how these realistic climate-induced changes due to increased watershed runoff and flow affected the proportion of the watershed classified with "High water vulnerability". 
Sensitivity of Drainage Basin Zones: Thomas Brook Watershed

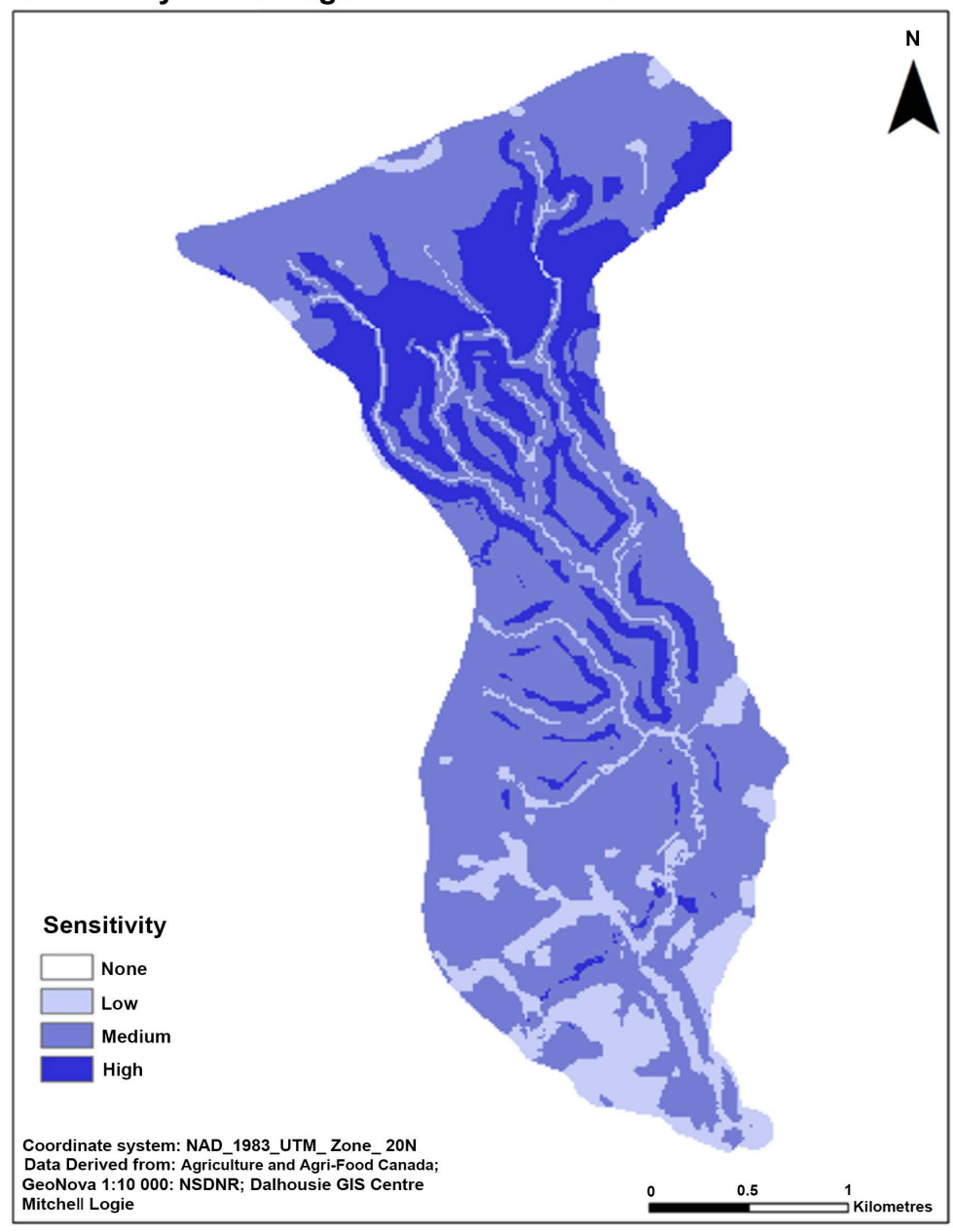

Figure 2. Sensitivity of drainage basin zones determined by the Purdum (1997) model as applied to Thomas Brook by France \& Pardy (2018), and described in the text.

Finally, we then examined how the establishment of forested riparian buffer strips might mitigate the projected effects of climate change. Here, four scenarios of differing widths of vegetative cover were investigated based on Ontario's recommended guidelines for riparian "areas of concern" (France et al., 2002; France, 2002a): $30 \mathrm{~m}, 50 \mathrm{~m}, 70 \mathrm{~m}$, and $90 \mathrm{~m}$ for lakes susceptible to acidification, food web manipulation, and deforestation (Howell et al., 1990; Ramcharan et al., 1996; France, 1995). All polygons within these distances from streams (the network of streams can be ascertained in Figure 2) were therefore ascribed to the forest category of landuse. Again, the final result of interest was the areal proportion of the watershed classified with "High water vulnerability", in this case under the respective scenarios of differing amounts of riparian reforestation.

\section{Results and Discussion}

\subsection{Climate Change and Watershed Flow}

The CRCM projected mean daily temperatures for the Bay of Fundy region of 
Nova Scotia from about $3.4^{\circ} \mathrm{C}$ (moderate past), to $5.0^{\circ} \mathrm{C}$ (present/near future), to $6.3^{\circ} \mathrm{C}$ (moderate future), to $8.3^{\circ} \mathrm{C}$ (more distant future) over the timespan from 1962 to 2099. Average annual precipitation is likewise projected to increase from about $11.2 \mathrm{~cm}$, to $11.6 \mathrm{~cm}$, to $11.5 \mathrm{~cm}$, to $12.2 \mathrm{~cm}$ over this period.

The WARMF model for the Thomas Brook watershed predicted progressive increases in annual flow in consequence of the CRCM predictions of climate change (Figure 3). Therefore, in comparison to the value for the "present/near future" (P/N F) time-period of 2011-2040 of $9.90 \pm 1.30 \mathrm{~m}$, future climate change is predicted to increase average annual watershed flow by about $10 \%$ for the "moderate or short-term future" (M F) period of 2041-2070 (i.e. 10.89 \pm 1.60 $\mathrm{m}$ ), and by about $30 \%$ for the "more distant or long-term future" (M D F) period of 2071-2099 (i.e. $12.82 \pm 1.48 \mathrm{~m}$ ).

\subsection{Climate Change and Surface Water Vulnerability}

Increasing the drainage intensity and drainage sensitivity rankings in the Purdum GIS model in consequence of the higher watershed flow projected to occur from climate change, increased the areal proportion of "High vulnerability" for the Thomas Brook watershed. Therefore, in comparison to the existing value 65.6\% previously determined for this watershed (France \& Pardy, 2018), the areal proportion designated as "High vulnerability" was elevated to between $78.1 \%$ and $89.3 \%$ depending on the scenario (Figure 4). Climate changes in drainage patterns are therefore predicted to enlarge the area of the Thomas Brook watershed deemed to be of "High vulnerability" for impacting surface water quality by as much as $16 \%$ to $24 \%$. The implications of such future conditions developing for Atlantic Canadian watersheds will be profound, necessitating serious examinations made of exactly where, what, and how landuse activities are, and should be, undertaken.

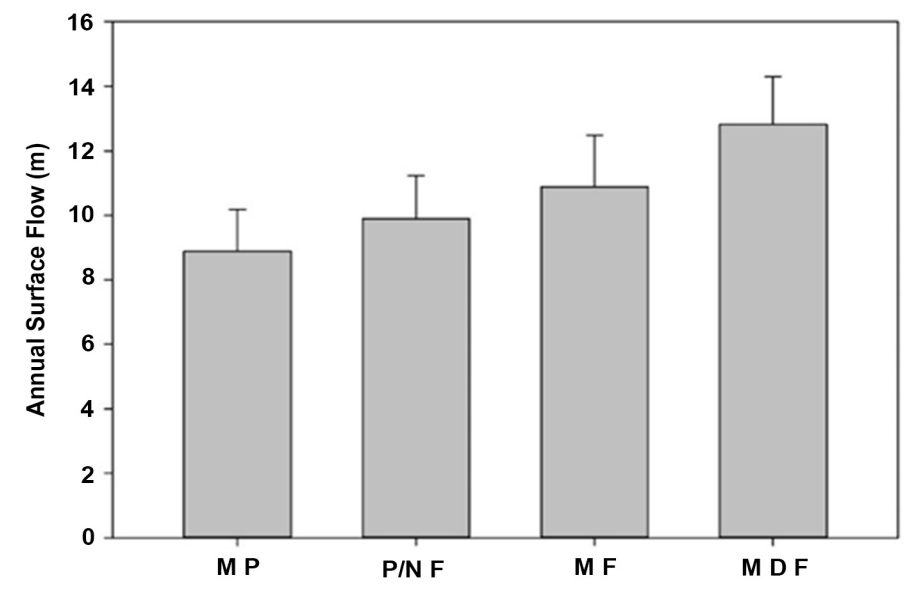

Figure 3. Projected mean $( \pm S D)$ annual surface flows $(m)$ for the Thomas Brook watershed under auspices of the climate change (CRCM, WARMF) model, as described in the text. Climate scenarios (left to right) are designated as $\mathrm{M} \mathrm{P}=$ Moderate past, $\mathrm{P} / \mathrm{N} \mathrm{F}=$ Present $/$ Near future, $\mathrm{M} \mathrm{F}=$ Moderate future, and M D F = More distant future. Samples sizes (from left to right) are 21 (M P), 36 (P/N F), 20 (M F), and 17 (M D F). 
High Vulnerability for Impacting Water Quality

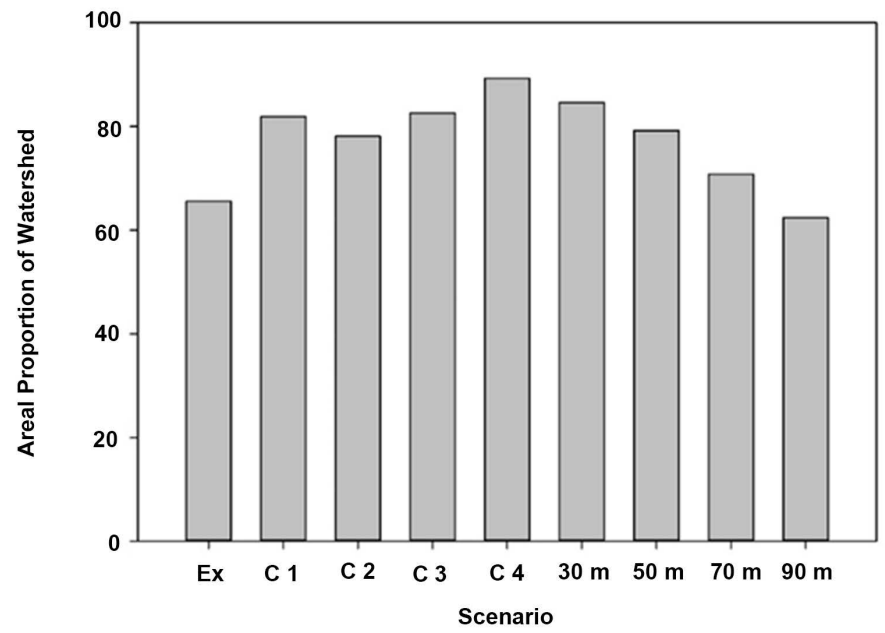

Figure 4. Estimated areal proportion of the Thomas Brook watershed characterized by the Purdum model as being "High vulnerability" for impacting surface water quality in response to predicted scenarios of climate changes in drainage patterns (designated as C 1, C 2, C 3, and C 4) and as ameliorated by riparian forest management (designated as buffer strip widths of $30 \mathrm{~m}, 50 \mathrm{~m}, 70 \mathrm{~m}$, and $90 \mathrm{~m}$ ), as described in the text. "Ex" = existing conditions as determined by France \& Pardy (2018).

The effect of nutrient export upon eutrophication is dependent on precipitation, runoff, and watershed flow, and can occur through two major transport pathways. Because nitrogen, the element limiting marine productivity, is exported from watersheds in aqueous form, control of flow is essential for managing the eutrophication of estuaries. Nitrogen export rates are susceptible to changes in climate, in particular to alterations in rainfall, due to being tightly coupled with flow (Dayyani et al., 2010, 2013). Previous work in the Thomas Brook watershed (Ahmad et al., 2011; Amon-Armah et al., 2013) using the SWAT model to simulate nonpoint source pollution, predicted tillage practices to have an influence on nitrate leaching and soil erosion. Because phosphorus, the element limiting freshwater productivity, can be transported through movement of soil particles, control of erosion is essential for managing the eutrophication of lakes and rivers. Soil erosion rates are susceptible to changes in climate, in particular to alterations in rainfall (Nearing et al., 2004; Hatfield \& Prueger, 2004), due to the erosive force of rain being directly related to both surface and inter ill erosion (France, 1997; France et al., 1998). Previous work for another watershed in Nova Scotia (France et al., 2018), using an integrated (GIS, RUSLE) model, predicted increases in total erosion rates of $4.9 \%$ to $9.9 \%$ over the next 25 years, and $25 \%$ for the subsequent quarter of a century.

\subsection{Mitigating Riparian Reforestation and Surface Water Vulnerability}

Establishing forested riparian buffer strips in the Purdum GIS model decreased 
the areal proportion of "High vulnerability" sites for the Thomas Brook watershed depending on the width scenario implemented. This occurred from the predicted value of $89.3 \%$ for climate change scenario 4 to values of $84.6 \%, 79.2 \%$, $70.8 \%$ and $62.4 \%$ with respect to corresponding buffer strips of $30 \mathrm{~m}, 50 \mathrm{~m}, 70$ $\mathrm{m}$, and $90 \mathrm{~m}$ width (Figure 4). Riparian reforestation is therefore predicted to have the potential to diminish the area of the Thomas Brook watershed deemed to be of "High vulnerability" for impacting surface water quality by up to $5 \%$ to $27 \%$. Significantly, only the implementation of a protective buffer of $90 \mathrm{~m}$ width resulted in a comparable watershed area of "High vulnerability" (i.e. 62.4\%) to that of present-day existing conditions (i.e. 65.6\% (France \& Pardy, 2018)). The implications for Atlantic Canadian watersheds will be of serious concern, as it could consequent reductions in the amount of land available for agricultural production and timber harvest.

Considerable experience in agricultural and timber management in Atlantic Canada has indicated that riparian zones there provide a large suite of ecosystem services for watersheds, with widths of $20 \mathrm{~m}$ generally being required along all watercourses in Nova Scotia. Such a width is consistent with recommendations for the region based on comprehensive reviews of the literature (Rideout, 2012; Stoffyn-Egli \& Duinker, 2013). In one study, for example, Vaidya et al. (2008) found nitrogen increased in Nova Scotia streams following clear cutting, with improvements in water quality ensuing through establishment of buffers of $20 \mathrm{~m}$ to $30 \mathrm{~m}$ in width. However, all these studies did not consider the implications of increased watershed flow on nutrient and sediment export in consequence of regional climate change projections. Toward this end, France et al. (2018) predicted buffer strips to reduce potential erosion rates by $11 \%$ to $32 \%$ depending on width for another Nova Scotian watershed, and that a width of $70 \mathrm{~m}$ would necessary in order to offset the increase in soil erosion predicted from climate change.

\section{Implications for Land Use Planning and Management}

The present analysis suggests that with greater proportions of the surface area of watersheds designated as being of "High vulnerability" with respect to impacting water quality under scenarios of future climate change, the contentious management decision of setting development caps to limit the amount of new sprawl (France, 2006) may need to be examined. As urbanization results in the highest amount runoff of any form of land use, adoption of low impact development (LID) practices such as rain gardens, bioretention swales, porous pavement, etc. (France, 2002b) could have to become de rigueur. For agricultural areas, which also generate substantial amounts of runoff, adoption of farming practices such as conservation tillage, crop rotation, flow diversion terracing, etc. (Yang et al., 2008, 2009) could also become essential.

Reforesting riparian buffers is recognized to be an important tool in overall watershed restoration (Williams, 1997). And Capron et al. (2013) will probably 
be proven correct in their prediction that over the next century riparian zones will become the "hotspots" for research and management concerning adaptation to climate change, as supported by another modeling by us (France et al., 2019). The present analysis suggests that employing a $90 \mathrm{~m}$ buffer strip to maintain the equivalent degree of environmental protection as presently exists in the face of future climate change, based on the areal extent of "High water vulnerability", will subsume more of the watershed. The result will be economic losses to the resource sector in consequence of having to expand buffer strip widths. In other words, climate-proofing such as watersheds through riparian reforestation will only come at a cost. Difficult trade-off decisions will therefore have to be made in terms of finding a societally-agreed upon balance between the areal extent of land that will be increasingly needed to be set aside in order to ensure surface water quality and that continued to be allotted for agricultural production and commercial forestry.

Although the present study site of the Thomas Brook watershed is one that was carefully selected by the Canadian Federal Government in consequence of it being deemed representative of many such in the region (AAFC, 2007), it is still only a single system. When one considers that the Purdum water vulnerability model (Purdum, 1997) is spatially-explicit and therefore closely dependent upon the idiosyncrasies of landscape topography and land use for the location to which it is applied, the limitation of the present study becomes obvious. The Thomas Brook watershed is characterized by a shallow channel slope (France \& Pardy, 2018). Additional research should be undertaken to model scenarios of future climate change for other watersheds of higher relief. In such cases, it is reasonable to predict that ameliorative land use planning with respect to buffer strip management could have a more dramatic influence on surface water vulnerability than that shown in the present study.

\section{Acknowledgements}

A Madani and S. Dayyani are thanked for technical assistance in developing the climate change model, as is G. Pardy, likewise, for the landuse model. This research was funded by an Agriculture and Agri-Food Canada Technical Development Grant, with support from the Nova Scotia Federation of Agriculture.

\section{Conflicts of Interest}

The authors declare no conflicts of interest regarding the publication of this paper.

\section{References}

AAFC (Agriculture and Agri-Food Canada) (2007). Watershed Evaluation of Beneficial Management Practices (WEBs).

Ahmad, H. M. N., Sinclair, A., Jamieson, R., Madani, A., Hebb, D., Havard, P., \& Yirodoe, E. K. (2011). Modeling Sediment and Nitrogen Export from a Rural Watershed in 
Eastern Canada Using the Soil and Water Assessment Tool. Journal of Environmental Quality, 40, 1182-1194. https://doi.org/10.2134/jeq2010.0530

Amon-Armah, F., Yirodoe, E. K., Ahmad, H., Hebb, D., Jamieson, R., Burton, D., \& Madani, A. (2013). Effect of Nutrient Management Planning on Crop Yield, Nitrate Leaching and Sediment Loading in Thomas Brook Watershed. Environmental Management, 52, 1177-1191. https://doi.org/10.1007/s00267-013-0148-Z

Cann, D., MacDougall, J., \& Hilchey, J. (1965). Soil Survey of Kings County, Nova Scotia. Report No. 15. Nova Scotia Soil Survey, Ottawa, Canada: Agriculture and Agri-Food Canada.

Capron, S. J., Chambers, L. E., MacNally, R., Naiman, R. J., Davies, P. et al. (2013). Riparian Ecosystems in the 21st Century: Hotspots for Climate Change Adaptation? Ecosystems, 16, 359-381. https://doi.org/10.1007/s10021-013-9656-1

Caya, D., \& Laprise, R. (1999). A Semi-Implicit Semi-Lagrangian Regional Climate Model: The Canadian RCM. Monthly Weather Review, 127, 341-362. https://doi.org/10.1175/1520-0493(1999)127<0341:ASISLR>2.0.CO;2

Chen, C. W., Herr, J., \& Ziemelis, L. (1998). Watershed Analysis Risk Management Framework-A Decision Support System for Watershed Approach and TMDL Calculation. Report TR110809. Electric Power Research Institute.

Dayyani, S., Prasher, S. O., Madani, A., \& Madramootoo, C. A. (2010). Development of DRAIN-WSRMF Model to Simulate Flow and Nitrogen Transport in a Tile-Drained Agricultural Watershed in Eastern Canada. Agricultural Water Management, 98, 55-68. https://doi.org/10.1016/j.agwat.2010.07.012

Dayyani, S., Prasher, S. O., Madani, A., Madramootoo, C. A., \& Enright, P. (2013). Evaluation of WARMF Model for Flow and Nitrogen Transport in an Agricultural Watershed under a Cold Climate. Water Quality Research Journal of Canada, 48, 400-413. https://doi.org/10.2166/wqric.2013.034

De Munck, C. S., Hutchings, T. R., \& Moffat, A. J. (2007). Impacts of Climate Change and Establishing a Vegetation Cover on Water Erosion of Contaminated Spoils for Two Contrasting United Kingdom Regional Climates: A Case Study Approach. Integrated Environmental Assessment and Management, 4, 443-455. https://doi.org/10.1897/IEAM_2008-016.1

El-Khoury, A., Seidou, O., Lapen, D. R., Que, Z., Mohannadian, M., \& Sunohara, M. (2015). Combined Impacts of Future Climate and Land Use Changes on Discharge, Nitrogen and Phosphorus Loads for a Canadian River Basin. Journal of Environmental Management, 151, 76-86. https://doi.org/10.1016/j.jenvman.2014.12.012

EPRI (2000). Peer Review of the Watershed Analysis Risk Management Framework (WARMF): An Evaluation of WARMF for TMDL Applications by Independent Experts Using USEPA Guidelines. TR1000252. Electric Power Research Institute.

Ferguson, B. K., \& Debo, T. N. (1989). On-Site Stormwater Management: Applications of Landscape and Engineering. New York: Van Nostrand Reinhold.

France, R. L. (1995). Macroinvertebrate Standing Crop in Littoral Regions of Allochthonous Detritus Accumulation: Implications for Forest Management. Biological Conservation, 71, 35-39. https://doi.org/10.1016/0006-3207(94)00018-L

France, R. L. (1997). Potential for Soil Erosion from Decreased Litterfall Due to Riparian Clearcutting: Implications for Boreal Forestry and Warm- and Cool-Water Fisheries. Journal of Soil and Water Conservation, 52, 452-455.

France, R. L. (2002b). Handbook of Water Sensitive Planning and Design. Boca Raton, FL: Lewis Publishers. 
France, R. L. (2006). Introduction to Watershed Development: Understanding and Managing the Impacts of Sprawl. Lanham, MD: Rowman and Littlefield.

France, R. L., \& Pardy, G. (2018). Spatially-Explicit, Exposure-Based Assessment of Surface Water Vulnerability from Land Use Threats for Time-Efficient and Cost-effective Watershed Development Planning. Journal of Geoscience and Environmental Protection, 6, 35-55. https://doi.org/10.4236/gep.2018.66003

France, R. L., Patton, A. S. M., \& Aitchison, P. W. (2019). Modeling Reforestation's Role in Climate-Proofing Watersheds from Flooding and Soil Erosion. American Journal of Climate Change. In Press.

France, R. L., Zhang, C., \& Brewster, G. R. (2018). Integrated Modeling of Soil Erosion for a Canadian Watershed in Response to Projected Changes in Climate and Consequent Adoption of Mitigating Best Management Practices. Journal of Geoscience and Environmental Protection, 6, 12-34.

France, R., Felkner, J. S., Flaxman, M., \& Rempel, R. (2002). Spatial Investigation of Applying Ontario's Timber Management Guidelines: GIS Analysis for Riparian Areas of Concern. In R. France (Ed.), Handbook of Water Sensitive Planning and Design (pp. 601-613). Boca Raton, FL: CRC Press.

France, R., Peters, R., \& McCabe, L. (1998). Spatial Relationships among Boreal Riparian Trees, Litterfall and Soil Erosion Potential with Reference to Buffer Strip Management and Coldwater Fisheries. Annals Botani Fennici, 35, 1-9.

France, R.L. (2002a). Factors Influencing Sediment Transport from Logging Roads near Boreal Trout Lakes (Ontario, Canada). In R. L. France (Ed.), Handbook of Water Sensitive Planning and Design (pp. 635-645). Boca Raton, FL: Lewis Publishers.

Hatfield, J. L., \& Prueger, J. H. (2004). Impacts of Changing Precipitation Patterns on Water Quality. Journal of Soil and Water Quality, 59, 51-58.

Howell, E. T., Turner, M. A., France, R. L., Jackson, M. B., \& Stokes, P. M. (1990). Comparison of Zygnematacean (Chlorophya) Algae in the Metaphyton of Two Acidic Lakes. Canadian Journal of Fisheries and Aquatic Sciences, 47, 1085-1092. https://doi.org/10.1139/f90-125

Jamieson, R., Gordon, R., Tattie S., \& Stratton, G. (2003). Sources and Persistence of Fecal Coliform Bacteria in a Rural Watershed. Water Quality Research Journal of Canada, 38, 33-47. https://doi.org/10.2166/wqrj.2003.004

Jones, J. A. (2011). Hydrologic Responses to Climate Change: Considering Geographic Context and Alternative Hypotheses. Hydrological Processes, 25, 1996-2000. https://doi.org/10.1002/hyp.8004

Keller, A., Zheng, Y., \& Robinson, T. (2004). Determining Critical Water Quality Conditions for Inorganic Nitrogen in Dry, Semi-urbanized Watersheds. Journal American Water Resources Association, 40, 721-735. https://doi.org/10.1111/j.1752-1688.2004.tb04455.x

Laprise, R., Caya, D., Giguere, G., Bergeron, H., \& Cote, J. P. (1998). Climate and Climate Change in Western Canada as Simulated by the Canadian Regional Climate Model. Atmosphere and Oceans, 36, 119-167. https://doi.org/10.1080/07055900.1998.9649609

Madani, A. (2009). Agricultural Water Management Systems and Strategies. Final Report. Canada-Nova Scotia Water Supply and Expansion Program.

Madani, A. (2010). Impact of Climate Change on Growing Season Soil Water Deficit and Surplus and on Nitrogen Pollution in Agricultural Watersheds in Nova Scotia. Unpublished Report, Nova Scotia: Nova Scotia Agricultural College.

Marsh, W. M. (1997). Landscape Planning: Environmental Applications. New York: John Wiley and Sons. 
Music, B., \& Caya, D. (2007). Evaluation of the Hydrological Cycle over the Mississippi River Basin as Simulated by the Canadian Regional Climate Model (CRCM). Journal of Hydrometeorology, 8, 969-988. https://doi.org/10.1175/JHM627.1

Nearing, M. A., Pruski, F. F., \& O’Neal, M. R. (2004). Expected Climate Change Impacts on Soil Erosion Rates: A Review. Journal of Soil and Water Conservation, 59, 43-49.

Novotna, B., van Bochove, E., \& Theriault, G. (2014). Potential Ecological Impact of Climate Change on the Water Quality of an Intensively Managed Agricultural Watershed in Quebec, Canada. Journal of Water and Climate, 5, 81-99. https://doi.org/10.2166/wcc.2013.121

Purdum, G. E. (1997). A Model for Identifying the Vulnerability of Streams and Rivers to Land Use-Induced Change. Landscape Research, 22, 209-224. https://doi.org/10.1080/01426399708706509

Ramcharan, C. W., France, R. L., \& McQueen, D. J. (1996). Multiple Effects of Planktivorous Fish on Algae through a Pelagic Trophic Cascade. Canadian Journal of Fisheries and Aquatic Sciences, 53, 2819-2828. https://doi.org/10.1139/f96-224

Rideout, E. (2012). Setbacks and Vegetated Buffers in Nova Scotia: A Review and Analysis of Current Practice and Management Options. Hydrologic Systems Research Group, Halifax: Dalhousie University.

Scinocca, J., \& McFarlane, N. (2004). The Variability of Modeled Tropical Precipitation. Journal of the Atmospheric Sciences, 61, 1993-2015. https://doi.org/10.1175/1520-0469(2004)061<1993:TVOMTP>2.0.CO;2

Sinclair, A., Hebb, D., Jamieson, R., Gordon, R., Benedict, K., Fuller, K., Stratton, G., \& Madani, A. (2009). Growing Season Surface Water Loading of Fecal Indicator Organisms within a Rural Watershed. Water Resources, 43, 1199-1206. https://doi.org/10.1016/j.watres.2008.12.006

Stoffyn-Egli, P., \& Duinker, P. N. (2013). An Ecological Approach to Riparian-Buffer Definition, and Implications for Timber Harvests in Nova Scotia, Canada. Journal of Sustainable Development, 6, 111-134. https://doi.org/10.5539/jsd.v6n12p111

Talib, A., \& Randhir, T. O. (2017). Climate Change and Land Use Impacts on Hydrologic Processes of Watershed Systems. Journal of Water and Climate, 8, 363-374. https://doi.org/10.2166/wcc.2017.064

Tong, S. T., Yang, H., Chen, H., \& Yang, J. Y. (2016). Hydrologic Impacts of Climate Change and Urbanization in the Las Vegas Wash Watershed, Nevada. Journal of Water and Climate, 7, 598-620. https://doi.org/10.2166/wcc.2016.038

USEPA (2009). Watershed Analysis Risk Management Framework (WARMF). http://www.epa.gov/athens/wwqtsc/html/warmf.html

Vaidya, O. C., Smith, T. P., Fernand, H., \& Leek, N. R. (2008). Forestry Best Management Practices: Evaluation of Alternate Streamside Management Zones on Stream Water Quality in Pockwock Lakes and Five Mile Lake Watersheds in Central Nova Scotia, Canada. Environmental Monitoring and Assessment, 137, 1-14. https://doi.org/10.1007/s10661-006-9370-y

Velasco, M., Cabello, A., Escaler, I., Barredo, A., \& Barrera-Escoda, A. (2014). Methodology for Risk Assessment of Flash Flood Events due to Climate and Land-Use Changes: Application to the Lloregat Basin. Journal of Water and Climate, 5, 204-215. https://doi.org/10.2166/wcc.2014.027

Williams, J. E. (1997). Watershed Restoration: Principles and Practices. Bethesda, MD: American Fisheries Society.

Yang, Q., Chow, T. L., Rees, H. W., \& Meng, F. R. (2008). Using a GIS and Digital Eleva- 
tion Model to Assess the Effectiveness of Variable Grade Flow Diversion Terraces for Reducing Soil Erosion in Northwestern New Brunswick. Hydrological Processes, HYP-07-0519.R1.

Yang, Q., Meng, F., Zhao, Z., Chow, T. L., \& Benoy, G. (2009). Assessing the Impacts of Flow Diversion Terraces on Stream Water and Sediment Yields at a Watershed Level Using SWAT Model. Agriculture, Ecosystems and Environment, 132, 23-31.

https://doi.org/10.1016/j.agee.2009.02.012 